p-ISSN: 1412-8187 e-ISSN: 2655-1284

email: lageografia@unm.ac.id

Jurusan Geografi Fakultas Matematika dan Ilmu Pengetahuan Alam

Universitas Negeri Makassar Sulawesi Selatan, Indonesia

Hernita Pasongli, Ramdani Salam, Wahyudi Tempola, 2021, Kesesuaian Objek Wisata Pantai Pas Ipa Kecamatan Mongoli Barat Kabupaten Kepulauan Sula

\title{
Land Suitability of The Pas Ipa Beach Tourims in Mangoli Barat Subdistrict, Sula Islands Regency
}

\author{
Hernita Pasongli $^{1}$, Ramdani Salam ${ }^{2}$, Wahyudi Tempola ${ }^{3}$ \\ ${ }^{123}$ PROGRAM STUDI PENDIDIKAN GEOGRAFI / FAKULTAS KEGURUAN DAN ILMU \\ PENDIDIKAN / UNIVERSITAS KHAIRUN
}

\author{
Email : \\ mukhtarnita@gmail.com ${ }^{1}$,danipalopo69@gmail.com², wahyudintempola@gmail.com ${ }^{3}$
}

(Received: Agu/2021; Reviewed: Sept/2021; Accepted: Sept/2021; Published: Okt/2021)

Ini adalah artikel dengan akses terbuka dibawah license CC BY-SA (C2021 oleh penulis (https://creativecommons.org/licenses/by-nc/4.0/).

\begin{abstract}
Tourism is one of the most important sectors in Indonesia after oil, natural gas and palm oil. The development of tourism in Indonesia is currently growing rapidly. This is because the tourism sector is very promising and provides benefits to many parties from the government, the public and the private sector. One of the special tourism objects in the West Mangoli sub-district of Sula Islands, North Maluku province is the Pas Ipa beach, however, the Pas Ipa beach tourism object has never been evaluated as an academic base for future development. This research uses descriptive quantitative method. With the physical parameters observed in Pas Ipa beach tourism objects, namely the diversity of flora, beach types, depth, slope, accessibility, brightness, beach width and tides. Besides that, the observation of infrastructure was also carried out. The results of the research on the Pas Ipa beach tourism object show that it is very suitable for the land for the Pas Ipa beach tourism object, which is in the S1 category. However, the facilities and infrastructure at Pas Ipa beach tourism objects need to be considered and improved.
\end{abstract}

Keywords: land suitability; beach tourism pas ipa

\section{ABSTRAK}

Pariwisata merupakan salah satu sektor terpenting di Indonesia setelah minyak, gas bumi dan kelapa sawit. Perkembangan pariwisata di Indonesia sekarang ini semakin pesat. Ini disebabkan sektor pariwisata sangat menjanjikan dan memberikan manfaat kepada banyak pihak dari pemerintah, masyarakat dan swasta. Salah satu obyek wisata khusus di kecamatan mangoli barat kepulauan sula provinsi maluku utara adalah pantai Pas Ipa, meski demikian obyek wisata pantai Pas Ipa belum pernah dilakukan evaluasi lahan obyek wisata sebagai landasan akademis untuk dikembangkan kedepan. Penelitian menggunakan metode deskriptif kuantitatif. Dengan parameter fisik yang diamati pada obyek wisata pantai Pas Ipa yaitu keragaman flora, tipe pantai, kedalaman, kemiringan lereng, aksebilitas, kecerahan, lebar pantai dan pasang surut. Selain itu dilakukan juga pengamatan sarana prasarana. Hasil penelitian pada obyek wisata pantai Pas Ipa menunjukkan sangat sesuai lahan untuk obyek wisata pantai Pas Ipa, yang berada 
Hernita Pasongli, Ramdani Salam, Wahyudi Tempola, 2021, Kesesuaian Objek Wisata

Pantai Pas Ipa Kecamatan Mongoli Barat Kabupaten Kepulauan Sula

pada ketegori S1. Meski demikian sarana dan prasarana pada obyek wisata pantai

Pas Ipa, perlu diperhatikan dan ditingkatkan.

Kata Kunci: kesesuaian lahan; wisata pantai pas ipa.

\section{PENDAHULUAN}

Hingga saat ini sektor pariwisata menduduki peringkat terbesar ketiga sebagai penyumbang devisa setelah migas dan tekstil. Diharapkan dengan meningkatkan sektor pariwisata dapat menciptakan lapangan pekerjaan sebagai upaya menyerap dan menciptakan pemerataan perekonomianpenduduk, pembangunan bidang perhotelan, transportasi dan lainnya yang menunjang kepariwisataan (Banowati, 2014). Pengembangan pariwisata di suatu daerah dipengaruhi oleh banyaknya parawisatawan yang berkunjung ke lokasi tersebut. Melakukan promosi dan media informasi yang massif merupakan indikator penting dalam meningkatkan jumlah kunjungan wisatawan (Erwin \& Zhiddiq, 2020). Menurut bahwa (Mustafa et al., 2020) setiap daerah memiliki objek wisata dengan keunikan masing-masing. Indonesia bagian timur juga memiliki objek wisata yang menarik untuk dikunjungi salah satunya di Kabupaten Kepulauan Sula. Kabupaten Kepulauan Sula sendiri terletak di Provinsi Maluku Utara. Daerah yang di sebelah utara berbatasan dengan laut Banda, Selatan dengan laut Seram, Barat dengan Laut Maluku, dan Timur dengan Sulawesi Tengah.

Kepulauan Sula menurut data dari Badan Pusat Statistik Kepulauan Sula, pada tahun 2019 jumlah wisata mengalami peningkatan yang sangat signifikan dibandingkan dengan beberapa tahun sebelumnya pada tahun 2015 jumlah wisatawan domestik 16.544 sedangkan mancanegara 40 orang, 2016 jumlah wisatawan domestik 19.200 dan 76 orang mancanegara, pada tahun 2017 jumlah wisatawan domestik 22.000 dan mancanegara 80. Sedangkan pada tahun 2018 jumlah wisatawan domestic 29.000 dan mancanegara 85 orang (Badan Pusat Statistik Kabupaten Kepulauan Sula, n.d.).

Salah satu obyek wisata di Kepulauan Sula adalah Pantai Pas. Pas Ipa terletak di Kecamatan Mangoli Barat, Perjalanan ke pantai pas Ipa membutuhkan waktu kurang lebih 4 jam apabila pengunjung melakukan perjalanan dari Sanana ibukota Kabupaten Kepulauan Sula dengan trasportasi laut. Pas Ipa mempunyai ciri khas pasir putih Panjang dengan terumbu karang di area pulau pas ipa yang sangat terjaga serta keunikan kearifan lokalnya. Ciri khas wisata dengan kondisi kearifan lokal merupakan daya tarik yang sangat relevan dikemas menjadi konsep ekowisata yang unik (Zulharman et al., 2017).

Keunikan obyek wisata Pas Ipa selain pasir putih panjang, ketika pasang surut pasir putih pun muncul, kemudian terumbu karang yang sangat indah dan masih sangat terjaga sehingga menarik para wisatawan berkunjung. Namun saat ini obyek wisata Pas Ipa kurang mendapat perhatian pemerintah kabupaten kepulauan sula. Untuk itu perlu ada perhatian ekstra dari pemerintah setempat untuk mengembangkan obyek wisata Pas Ipa. Salah satu upaya untuk memudahkan pemerintah bersama masyarakat serta stake holder lainnya dalam 
mengembangkan obyek wisata pantai Pas Ipa agar menjadi wisata andalan yang banyak dikunjungi wisatawan adalah dengan cara melakukan evaluasi kesesuaian lahannya.

Sebagaimana dikemukakan (Pasongli \& Dirawan, 2016) evaluasi lahan merupakan proses pemberian nilai terhadap penampilan performance lahan jika dipergunakan untuk tujuan tertentu, meliputi pelasanaan dan interprestasi survai, studi bentuk lahan, tanah, vegetasi, iklim dan aspek lahanlainnya, agar dapat mengidentifikasi dan membuat perbandingan berbagai penggunaan lahan yang mungkin akan dikembangkan, salah satunya yang ada diwilayah pesisir. Menurut (Rinaldi et al., 2020) bahwa sektor pesisir merupakan kawasan yang membentuk batasan antara daratan dan laut yang memanjang yang sangat tergantung pada keadaan topografi.

Selain itu pariwisata pantai dapat meningkatkan perekonomian masyarakat sekitar dengan adanya pengembangan lahan pantai maka diperlukan data informasi tentang potensi kawasan (kelayakan lahan). Kurangnya keterampilan yang dimiliki masyarakat, membuat mereka lebih memilih memanfaatkan sumber daya yang ada sebagai mata pencaharian pokok (Saputro et al., 2019). Menurut (Rudiastuti, 2011) bahwa kesesuaian lahan sangat penting dilakukan karena lahan memiliki sifat fisik, sosial, ekonomi dan geografi yang bervariasi atau lahan diciptakan tidak sama. Menurut (Hutabarat et al., 2009) Aspek yang paling penting dalam konsep pemanfaatan sumber daya alam untuk tujuan wisata adalah kesesuaian sumber daya dan daya dukung kawasan yang mendukung kegiatan. Selain itu, menurut (Zulharman et al., 2017) bahwa nilai estetik keindahan alam dan keanekaragaman adat dan budaya daerah merupakan modal dasar yang dapat dikembangkan menjadi produk wisata yang menarik bagi wisatawan.

Berdasarkan permasalahan tersebut, peneliti tertarik untuk mengkaji lebih dalam terkait kesesuaian objek wisata pantai pas ipa yang berada di Kecamatan Mongoli Barat Kabupaten Kepulauan Sula.

\section{METODE}

Metode yang digunakan dalam penelitian ini adalah Deskriptif dengan pendekatan Kuantitatif. Menurut (Sukmadinata Nana, 2010) menyatakan bahwa penelitian deskriptif adalah suatu metode penelitian yang ditujukan untuk menggambarkan fenomena yang ada, yang berlangsung pada saat ini atau lampau, sementara Kuantitatif ialah hitungan numerik/angka.

Penelitian ini akan dilaksanakan di Area Pantai Pas Ipa yang merupakan salah satu lokasi wisata yang terdapat di Kecamatan Mangoli Barat, Kabupaten Kepulauan Sula Maluku Utara. Peta lokasi penelitian dapat dilihat pada gambar berikut: 


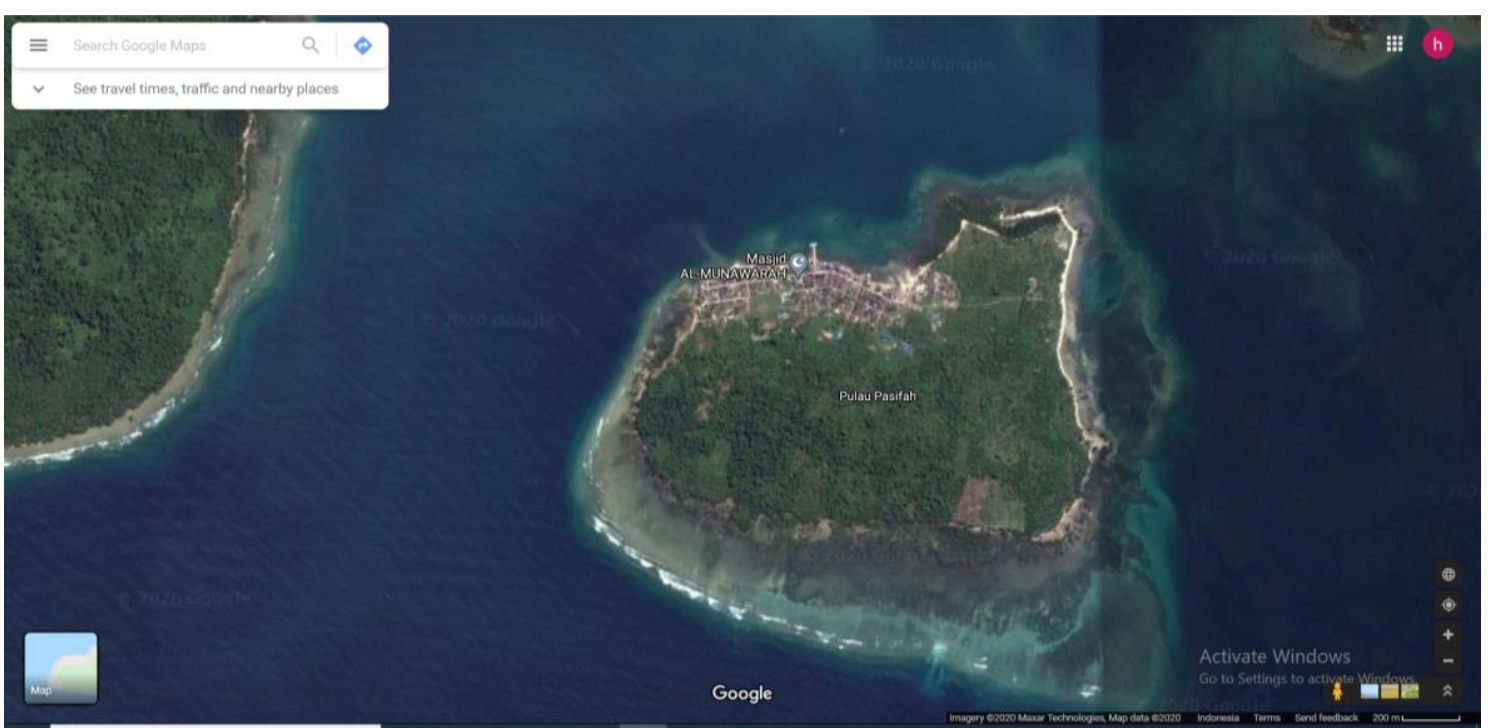

Gambar 1. Peta Lokasi Penelitian

Menurut (Sugiyono, 2019) bahwa "populasi adalah wilayah generalisasi yang terdiri atas obyek/subyek yang mempunyai karakteristik tertentu yang di terapkan oleh peneliti untuk dipelajari dan kemudian ditarik kesimpulan". Berdasarkan pengertian tersebut, maka populasi dalam penelitian ini adalah kesatuan parameter biologis dan geofisik yang ada di wilayah pantai Pas Ipa, Kecamatan Mangoli Barat, Kabupaten Kepulauan Sula.

Sampel merupakan bagian dari populasi, maka harus mewakili ciri-ciri yang terdapat dalam populasi tersebut. Sampel merupakan bagian dari populasi yang akan diteliti atau sebagian jumlah dari karakteristik yang dimilki oleh populasi. Pengambilan sampel harus dilakukan sedemikian rupa sehingga diperoleh sampel yang benar-benar dapat berfungsi sebagai contoh atau dapat menggambarkan keadaan yang sebenarnya (Arikunto, 2019).

Berdasarkan definisi sampel tersebut maka, sampel dalam penelitian ini adalah kesatuan parameter biologis dan geofisik yang ada di wilayah area Pas Ipa, Kecamatan Mangoli Barat (Area Sampling), dengan teknik pengambilan sampel menggunakan"Purposive Rondom Sampling", yaitu teknik pengambilan merupakan tehnik pengambilan sampel dengan memperhatikan pertimbangan-pertimbangan yang dibuat oleh peneliti (Suharsimi, 2006). Adapun sampel dalam penelitian ini yaitu keragaman flora, tipe pantai, kedalaman, kemiringan lereng, aksesibilitas, kecerahan, lebar pantai dan pasang surut air laut.

Pengambilan data di lapangan dilakukan dengan mengambil data sesuai dengan kondisi aktual.

1. Identifikasi Keragaman dan Dominansi Jenis Tumbuhan Pantai (Mangrove dan Non Mangrove)

- Menentukan garis lintasan/stasiun pengamatan;

- Membuat plot ukuran 10 x 10 m dengan menggunakan tali arafiah/roll meter;

- Mengidentifikasi setiap jenis tumbuhan yang terdapat di dalam plot tersebut ke dalam 
Hernita Pasongli, Ramdani Salam, Wahyudi Tempola, 2021, Kesesuaian Objek Wisata Pantai Pas Ipa Kecamatan Mongoli Barat Kabupaten Kepulauan Sula

tabel pengamatan;

2. Tipe pantai

- Pengambilan dan pengamatan sampel sediman dilakukan secara acak pada beberapa titik saja untuk mewakili tipe pantai

3. Lebar Pantai

- Mengukur jarak antara vegetasi terakhir yang berada di pantai dengan batas pasang tertinggi menggunakan rool meter

4. Pasang Surut dan kemiringan lereng

- Mencari data/ literature pasang surut air laut.

5. Kedalaman

- Membuat tali skala yang dilengkapi dengan pemberat;

- Mengukur jarak bibir pantai ke perairan kurang lebih $150 \mathrm{~m}$;

- Memasukkan tali skala yang dilengkapi pemberat ke dalam air; dan

- Meletakkan tali skala tersebut pada 3 stasiun pengamatan

6. Kecerahan

Pengukuran kecerahan sering dilakukan dengan menggunakan alat yang disebut secchi disc (keeping secchi). Dengan memasukkan piringan ke dalam air hingga tidak terlihat lagi warnanya, kemudian di ukur dengan meteran. Selanjutnya pengukuran kecerahan mengacu pada rumus berikut:

$$
\mathrm{K}=\frac{\mathrm{T} 1+\mathrm{T} 2}{2}
$$

Dimana $\mathrm{K}=$ Kecerahan

$\mathrm{T} 1$ = Kedalaman secchi disk hilang

$\mathrm{T} 2=$ Kedalaman secchidisk terlihat ketika ditarik kembali dari perairan

Analisis kesesuaian (suitability analysis) lahan dimaksudkan untuk mengetahui kesesuaian lahan wisata pantai secara spasial dengan menggunakan konsep evaluasi lahan. Sebagaimana ditunjukkan pada tabel berikut.

Tabel 1. Evaluasi kesesuaian lahan obyek wisata

\begin{tabular}{|c|c|c|c|c|c|c|c|}
\hline Paramater & Bobot & Kategori S1 & Skor & Kategori S2 & Skor & Kategori N & Skor \\
\hline $\begin{array}{l}\text { Keragaman } \\
\text { Flora } \\
\text { (Tumbuhan } \\
\text { Pantai) }\end{array}$ & 2 & $\begin{array}{l}\text { Mangrove, } \\
\text { pescaprae, } \\
\text { barringtonia }\end{array}$ & 3 & $\begin{array}{l}\text { Pescaprae, } \\
\text { barringtonia }\end{array}$ & 2 & $\begin{array}{c}\text { Non } \\
\text { vegetasi } \\
\text { /rumput- } \\
\text { rumputan }\end{array}$ & 1 \\
\hline $\begin{array}{l}\text { Tipe Pantai } \\
\text { Berdasarkan } \\
\text { Substrat } \\
\text { (visual) }\end{array}$ & 1 & Berpasir & 3 & $\begin{array}{c}\text { Berpasir, } \\
\text { sedikit } \\
\text { karang }\end{array}$ & 2 & Berlumpur & 1 \\
\hline $\begin{array}{l}\text { Kedalaman } \\
\text { (m) }\end{array}$ & 2 & $0-3$ & 3 & $3-6$ & 2 & $>6$ & 1 \\
\hline
\end{tabular}


Hernita Pasongli, Ramdani Salam, Wahyudi Tempola, 2021, Kesesuaian Objek Wisata Pantai Pas Ipa Kecamatan Mongoli Barat Kabupaten Kepulauan Sula

\begin{tabular}{|c|c|c|c|c|c|c|}
\hline $\begin{array}{l}\text { Kemiringan } \\
\text { lereng }\end{array}$ & 1 & Datar / Landai & 3 & Curam & 2 & Terjal \\
\hline Aksesibilitas & 1 & baik & 3 & Sedang & 2 & Buruk \\
\hline $\begin{array}{l}\text { Kecerahan } \\
(\%)\end{array}$ & 1 & $80-100$ & 3 & $50-<80$ & 2 & $<50$ \\
\hline $\begin{array}{l}\text { Lebar Pantai } \\
\text { (m) }\end{array}$ & 1 & $>10$ & 3 & $3-<10$ & 2 & $<3$ \\
\hline $\begin{array}{l}\text { Pasang surut } \\
\text { air laut }\end{array}$ & 1 & 2 meter & 3 & $0,5-2$ meter & 2 & $<0,5$ meter \\
\hline
\end{tabular}

Beberapa parameter fisika dihubungkan dengan kondisi biologi dan geomorfologi untuk menjadi parameter acuan untuk kesesuaian lahan wisata pantai.

Analis data secara deskriptif kualitatis dan metode matching setelah itu menggunakan metode scoring, Rumus yang digunakan yaitu Analisis Data mengunakan system pemberian skor yang mengacu pada (Rudiastuti, 2011):

Dimana :

$$
\mathbf{N}=\sum(\mathbf{W i} \mathbf{x} \mathbf{S i})
$$

$\mathrm{N}$ = Nilai total kesesuaian lahan

$\mathrm{Wi}=$ Bobot $($ weigth $)$

$\mathrm{Si}=$ Nilai (skor)

Atau

\section{SHB $=$ Bobot $x$ Nilai Skoring}

Dimana: SHB $=$ Skor akhir setelah penjumlahan nilai semua parameter

Atau

Keterangan :

$$
\mathrm{IKW}=\sum \frac{\mathrm{Ni}}{\mathrm{Nmax}} \mathbf{X} 100 \%
$$

IKW = Indeks Kesesuaian Wisata

$\mathrm{Ni} \quad=$ Nilai parameter ke-i (Bobot $\mathrm{x}$ Skor)

Nmaks = Nilai maksimum dari suatu kategori wisata

Selanjutnya terbagi atas 4 kelas-kelas kesesuaian lahan yaitu sebagai beriukut: Nilai maksimum: 30

S1: Sangat Sesuai $(>19)$,

S2: Sesuai (13 -18).

S3: Sesuai Bersyarat $(<12)$

\section{HASIL DAN PEMBAHASAN}

\section{Hasil}

Secara letak geografis, Desa Pas Ipa berada di kecamatan Mangoli Barat, Kabupaten 
Hernita Pasongli, Ramdani Salam, Wahyudi Tempola, 2021, Kesesuaian Objek Wisata Pantai Pas Ipa Kecamatan Mongoli Barat Kabupaten Kepulauan Sula

Kepulauan Sula, Provinsi Maluku Utara. Desa Pas Ipa berada pada titik Koordinat $00^{\circ}$ 50'36.82"N- 127²0'33.54"E. Desa Pas Ipa, terletak pada pulau Pas Ipa. Terpisah dari pulau mangoli dan sulabesi. Sebagaimana ditunjukkan Gambar 2.

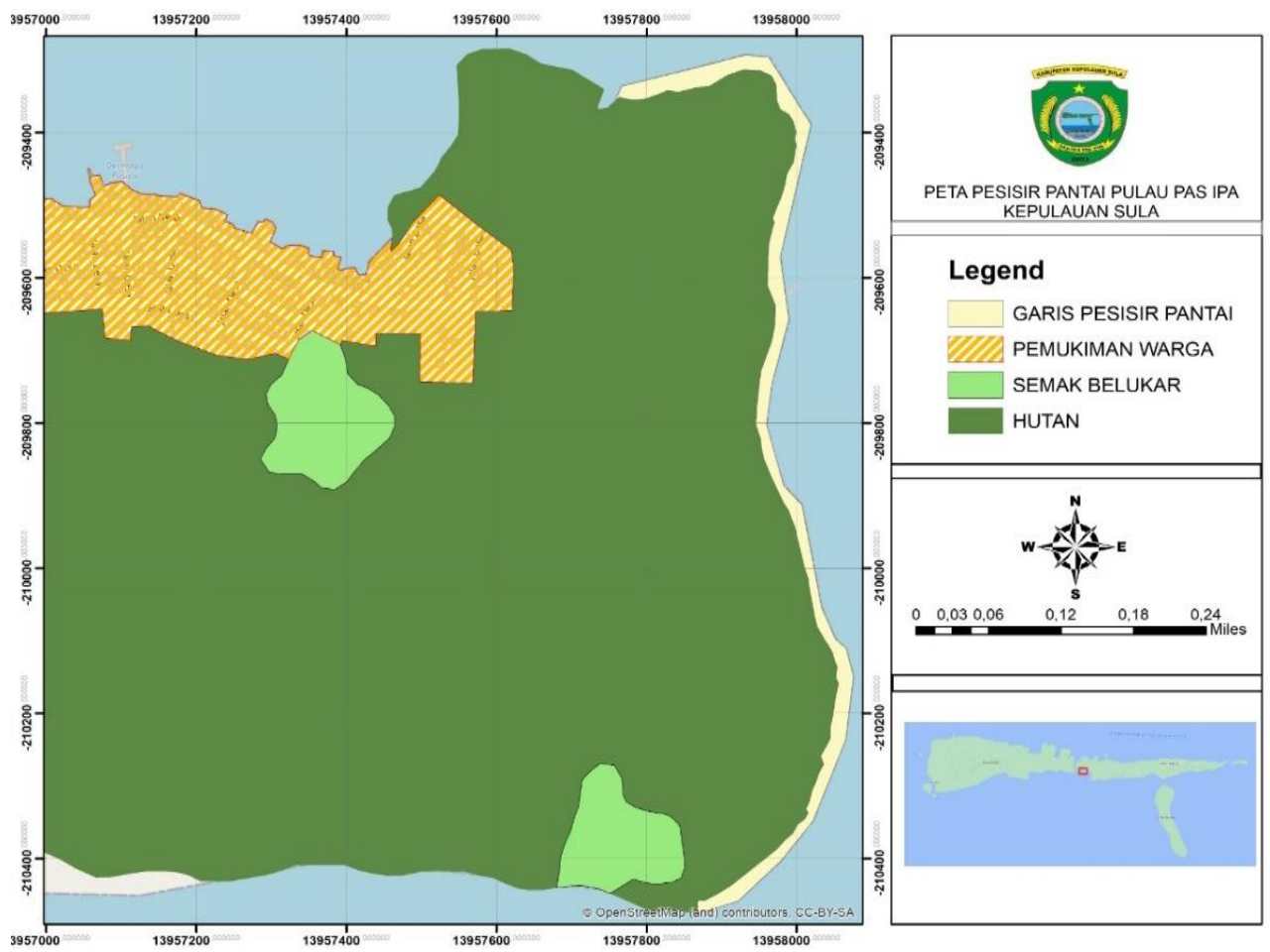

Gambar 2. Peta Lokasi Penelitian

Desa Pas Ipa berada di Kecamatan Mangoli Barat, Kabupaten Kepulauan Sula, Provinsi Maluku Utara. Berhadapan dengan desa Johor dan Leleyaba. Di sebelah barat terdapat Selat Capalulu dan sebelah timur terdapat Batu Kapitang. Kondisi kependudukan desa Pas Ipa jumlah penduduk Desa Pas Ipa 1572 orang dengan 872 orang berjenis kelamin laki-laki dan 700 orang berjenis kelamin perempuan. Adapun jumlah kepala keluarga (KK) di Desa Pas Ipa sebanyak $300 \mathrm{KK}$ dengan kepadatan penduduk $4 \mathrm{jiwa} / \mathrm{km} 2$. Adapun rata-rata anggota keluarga sebanyak 5 jiwa. sarana pendidikan yang ada yaitu Terdapat 1 TK, 2 SD Negeri, 1 SMP Negeri, dan 1 SMK Negeri. Pelayanan kesehatan yang tersedia yaitu, terdiri dari 1 Pustu. Mayoritas penduduknya adalah muslim, serta memiliki 1 Masjid dan 1 Mushollah, sebagai sarana ibadah. Untuk sarana perekonomian terdapat 16 kios/warung, dengan mata pencaharian penduduk di Desa Pas Ipa adalah cenderung mengarah pada bidang pertanian dan perikanan. Adapu jaringan komunikasi, di Desa Pas Ipa Akses komunikasi sangat lancar karena terdapat 1 tower mini telkomsel dan mendapat jaringan tower telkomsel yang kapasitas besar dari desa tetangga yaitu desa Buya. 
Jenis vegetasi penutup yang tumbuh di pantai Pas Ipa, pada stasiun I lebih didoiminasi dengan tumbuhan yang tergolong dalam tumbuhan non-manggrove yang membentuk formasi barringgtonia dan Pes-caprae. Kondisi tumbuhan di pantai Pas Ipa cukup beragam tersebar pada habitatnya masing-masing. Hasil kesesuaian yang diperoleh yaitu pada kelas S1dengan skor 3 bobot 2. Adapun hasil pengamatan untuk keragaman flora pada pantai Pas Ipa ditunjukkan pada informasi berikut:

Tabel 2. Keragaman Flora Pantai Pas Ipa

\begin{tabular}{llll}
\hline No & \multicolumn{1}{c}{ Nama lokal } & \multicolumn{1}{c}{ Nama Ilmiah } & \multicolumn{1}{c}{ Indonesia } \\
\hline 1 & Kat-kat & Cosmos caudatus & kenikir \\
2 & Katang-katang & Merremia peltata & Kangkung laut \\
3 & Pohon kelapa & Cocos nucifera & Pohon kelapa \\
4 & Manggi-Manggi & Rhizophora stylosa Griff & Mangrove \\
\hline
\end{tabular}

Pengamatan tipe pantai di area obyek wisata pantai Pas Ipa, yaitu berpasir dengan warna putih sehingga termasuk kategori S1 (sangat sesuai), dengan skor 3. Berdasarakan hasil pengamatan dan pengukuran tingkat kedalaman pantai Pas Ipa yaitu diperoleh kedalaman $2 \mathrm{~m}$, sehingga mendapat skor 3 sesuai dengan tabel kesesuaian lahan. Dengan kedalaman yang termasuk kategori S1 (sangat sesuai), dengan skor 3, maka sangat sesuai untuk aktivitas wisata bermain air, renang dan berperahu. Kegiatan pengukuran kedalaman perairan Pantai Pas Ipa.

Dari hasil pengukuran kemiringan Pantai Pas Ipa, diperoleh kemiringan pantai $10^{\circ}$, kategori S2 ( sesuai), dengan skor 2. Kondisi kemiringan pantai di Pantai Pas Ipa, cukup sesuai dan tergolong datar, untuk aktivitas wisata bermain pasir dan renang. Pengukuran kecerahan di Pantai Pas Ipa, diperoleh kecerahan, yaitu diperoleh tingkat kecerahan terlihat pada kedalaman 2 meter, sementara kecerahan tidak terlihat pada kedalaman 4 meter, sehingga diperoleh tingkat kecerahan yaitu :

$$
\begin{aligned}
& K=\frac{T 1+T 2}{2} \\
& K=\frac{2+4}{2}=3
\end{aligned}
$$

Untuk pasang surut air laut ini diperoleh bahwa kelayakan atau tingkat kesesuaian berada pada S2 atau dikatagorikan sesuai. Dari segi parameter fisik pantai Pas Ipa sangat sesuai untuk dijadikan obyek wisata pantai meski demikian fasilitas sarana dan prasarana meski ditingkatkan. Hal ini berdasarkan pengamatan bahwa sarana dan prasarana masih sangat kurang. Untuk pemerintah desa harus lebih proaktif komunikasi dengan dinas terkait pada pemerintah kabupaten kepulauan sula untuk meningkatkan sarana dan prasarana pada pantai pas ipa.

Kelayakan pantai Pas Ipa diukur pada stasiun dengan koordinat -1.8823 125.3870 telah menunjukkan bahwa Pantai Pas Ipa yang berada di Kecamatan Mangoli Barat Kabupaten Kepulauan sula memiliki kelayakan yang sangat sesuai atau masuk pada kategori S1 sebagai pariwisata pantai. 
email: lageografia@unm.ac.id

Jurusan Geografi Fakultas Matematika dan Ilmu Pengetahuan Alam

Universitas Negeri Makassar Sulawesi Selatan, Indonesia

Hernita Pasongli, Ramdani Salam, Wahyudi Tempola, 2021, Kesesuaian Objek Wisata Pantai Pas Ipa Kecamatan Mongoli Barat Kabupaten Kepulauan Sula

Selanjutnya untuk mendapatkan nilai indeks kesesuaian lahan pariwisata pantai Pas Ipa dengan menggunakan metode Matching setiap parameter dapat dilihat pada Tabel 3.

Tabel 3. Tingkat Kesesuaian Wisata Pantai Pas Ipa

\begin{tabular}{|c|c|c|c|c|c|}
\hline No & Parameter & Bobot & Hasil & Skor & $\mathbf{N i}$ \\
\hline 1 & Keragaman Flora & 2 & $\begin{array}{l}\text { Pohon Kelapa, } \\
\text { Mangrove }\end{array}$ & 3 & 6 \\
\hline 2 & Tipe Pantai & 1 & Berpasir & 3 & 3 \\
\hline 3 & Kedalaman & 2 & $2 \mathrm{~m}$ & 3 & 6 \\
\hline 4 & Kemiringan Lereng & 1 & Datar/landai & 2 & 2 \\
\hline 5 & Aksebilitas & 1 & Sedang & 2 & 2 \\
\hline 6 & Kecerahan & 1 & $80 \%$ terlihat & 3 & 3 \\
\hline 7 & Lebar Pantai & 1 & $13 \mathrm{~m}$ & 3 & 3 \\
\hline 8 & Pasut & 1 & 0,6 & 2 & 2 \\
\hline & Total skor & & & 21 & 27 \\
\hline \multicolumn{5}{|c|}{ Nilai maksimum } & 30 \\
\hline \multicolumn{5}{|c|}{ Skor tertinggi } & $0,9 \%$ \\
\hline \multicolumn{5}{|c|}{ Indeks kesesuaian wisata } & $90 \%$ \\
\hline \multicolumn{5}{|c|}{ Kategori tingkat kesesuaian } & S1 \\
\hline
\end{tabular}

Sumber: Hasil analisis data, 2021

Dari hasil analisis data yang diperoleh berdasarkan parameter bahwa Indeks Kesesuaian Lahan (IKW) di Pantai Pas Ipa pada stasiun yaitu $90 \%$, sehingga Pantai Pas Ipa termasuk dalam kategori S1 (Sesuai) sebagai salah satu lokasi wisata pantai dan pariwisata di Pas Ipa, Kecamatan Mangoli Barat, Kabupaten Kepulauan Sula.

Berdasarkan data diatas maka Hasil penelitian dapat disajikan pada Tabel berikut ini:

Tabel 4. Hasil Penelitian Evaluasi Lahan Pantai Pas Ipa

\begin{tabular}{lll}
\hline No & \multicolumn{1}{c}{ Parameter } & \multicolumn{1}{c}{ Keterangan } \\
\hline 1 & Keragaman Flora & Sangat Sesuai (S1) \\
2 & Tipe Pantai & Sangat Sesuai (S1) \\
3 & Kedalaman Perairan & Sangat Sesuai (S1) \\
4 & Kemiringan Lereng & Sesuai (S2) \\
5 & Kecerahan & Sangat Sesuai (S1) \\
6 & Lebar Pantai & Sangat Sesuai (S1) \\
7 & Pasang Surut Air Laut & Sesuai (S2) \\
8 & Sarana dan Prasarana & Cukup Sesuai (S3) \\
\hline
\end{tabular}

Sumber: Hasil analisis data, 2021

\section{Pembahasan}

Parameter kesesuaian kawasan wisata pantai Pas Ipa dimana meliputi keragaman flora, tipe pantai, lebar pantai, kedalaman, kemiringan lereng, material dasar perairan, kemiringan 
pantai, aksesbilitas, kecerahan, lebar pantai, kecepatan arus. Hasil pengamatan dan perhitungan kesesuaian kawasan wisata Pantai Pas Ipa, adalah sebagai berikut:

1. Keragaman Flora (Tumbuhan pantai)

Pada umumnya, dalam kajian kesesuaian lahan pantai digolongkan kedalam dua kategori, yaitu tumbuhan mangrove (pes-caprae) dan Non manggrove( barringtonia). Formasi barringtonia adalah formasi yang lebih banyak didominasi oleh tumbuhan berupa pohon.Sedangkan, formasi pes-caprae Adalah komunitas tumbuhan yang merupakan bagian dari vegetasi perintis yang terdapat pada garis pantai (shore line) pesisir di belakang jangkauan pasang tertinggi, serta banyak tumbuh di gundukan pasir (Noor et al., 2006). Pantai merupakan perbatasan antara ekosistem darat dan ekosistem laut. Hempasan gelombang pasir yang membawa pasir kedaratan sehingga membentuk gundukan, gundukan inilah yang disebut hutan pantai, yang berada di tepi pantai. Pada daerah inilah biasanya tumbuh beberapa tumbuhan yang tahan terhadap kadar garam yang tinggi.

2. Tipe Pantai

Tipe pantai di Indonesia diidentifikasi terdapat tiga jenis utama tipe pantai yang dapat dibedakan berdasarkan sedimen atau substrat, yaitu pantai berpasir, pantai berlumpur, pantai berkarang (Ardian, 2015),. Tipe pantai ini dapat dilihat dari jenis substratnya yang dilakukan pengamatan secara visual.

3. Kedalaman

Kedalaman perairan merupakan aspek yang cukup penting untuk diperhitungkan untuk penentuan suatu kawasan untuk dijadikan sebagai kawasan wisata pantai khususnya mandi dan renang karena sangat berpengaruh pada aspek keselamatan pada saat berenang, dimana kedalaman haruslah relatif dangkal (Armos, 2013),

4. Kemiringan Lereng

Menurut (Hutabarat et al., 2009), kemiringan pantai yang landai agak sedikit datar akan membuat para wisatawan yang berkunjung merasa aman dan nyaman melakukan kegiatan wisata di sekitar pesisir dan laut.

5. Kecerahan

Kecerahan perairan selain menjadi parameter kualitas perairan, kecerahan perairan juga termasuk digunakan juga sebagai parameter kesesuaian wisata. Yaitu untuk menjadi salah satu parameter yang mencirikan nilai keindahan pemandangan saat melakukan berbagai kegiatan wisata. Semakin dalam penetrasi intesitas cahaya matahari menembus kedalaman perairan lautmaka semakin bagus dan indah pemandangannya.

6. Lebar pantai

Lebar pantai berkaitan dengan luasnya Lahan pantai yang dapat dimanfaatkan untuk berbagai aktivitas wisata pantai (Rahmawati, 2009). Lebar pantai yang sangat sesuai untuk wisata pantai adalah lebih dari 15 meter, Sedangkan untuk lebar pantai kurang dari 3 meter dianggap tidak sesuai untuk wisata pantai. Menurut Armos (2013), pengukuran lebar pantai dimaksudkan untuk mengetahui seberapa besar wilayah pantai yang dapat digunakan untuk 
berbagai kegiatan wisata pantai. Dari hasil pengukuran dilapangan diperoleh lebar pantai yaitu $13 \mathrm{~m}$.

7. Pasang Surut Air Laut

Pasang surut adalah fenomena alam yang terjadi pada air laut, permukaan air laut akan mengalami naik turun secara teratur dan berulang-ulang yang dapat menyebabkan pergerakan partikel massa air daripermukaan sampai ke dasar laut (effendi, dkk. 2017). Fenomena pasang surut air laut diartikan sebagai fenomena pergerakan naik turunnya permukaan air laut secara berkala yang diakibatkan oleh pengaruh dari kombinasi gaya gravitasi dari benda-benda astronomis terutama matahari dan bulan serta gaya sentrifugal bumi. Pengaruh gravitasi benda angkasa lain (selain bulan dan matahari) dapat diabaikan karena jaraknya lebih jauh atau ukurannya lebih kecil. Pasang surut di Pantai Desa Pas Ipa tergantung bulan-bulan tertentu, sebagaimana yang didapatkan dari http://tides.big.go.id/pasut/ disertai pengamatan langsung pada bulan Desember, pasang surut naik tidak terlalu tinggi begitu sebaliknya

8. Fasilitas dan Sarana Pra Sarana Pantai Pas Ipa

Pantai Pas Ipa dikelola oleh pemerintah desa Pas Ipa. Fasilitas pendukung untuk membantu mempercantik diarea pantai Pas Ipa, seperti Gajebo pun sudah dibangun oleh pemerintah Desa Pas Ipa. Namun hingga hari ini pemerintah Desa Pas Ipa, belum membangun komunikasi yang baik dengan dinas terkait di Kabupaten Kepulauan Sula. Untuk sampai di desa Pas Ipa, baik dari desa tetangga maupun dari luar desa tetangga harus tempuh dengan jalur laut. Desa Pas Ipa memiliki Pelabuhan laut yang memadai hanya saja kapal penumpang belum berani sandar di dermaga desa Pas Ipa, sehingga kapal harus berlabuh jika ingin menurunkan penumpang baik dari Sanana, Ternate dan Taliabu.

Pelabuhan desa Pas Ipa sangat strategis karena angin apapun Pelabuhan tetap aman. Hal inilah yang membuat kapal penumpang dari Ternate pun masuk di Pas Ipa. Di area pantai juga terdapat WC yang jaraknya kurang lebih $100 \mathrm{~m}$ dari lokasi pantai. ketersesian air tawar di pantai Ipa Ipas juga belum memenuhi syarat dalam pengembangan wisata pantai hal ini disebabkan karena air bersih dipergunakan pengunjung untuk membersihkan badan setelah melakukan aktivitas berenang. Menurut (Pasongli et al., 2020) menjelaskan sumber air tawar mutlak diperlukan, terutama untuk kelangsungan hidup penduduk dan menunjang pengembangan potensi ke pariwisataan di wilayah pulau-pulau kecil

Parameter fisik merupakan kriteria kelayakan pantai untuk tujuan pariwisata. Dalam tinjauan parameter fisik pantai Pas Ipa untuk kesesuaian wisata pantai, digunakan pengukuran parameter fisik pantai yang sekiranya mendukung kegiatan pariwisata. Keragaman flora pada pantai Pas Ipa sangat baik, hal ini karena sepanjang pantai terdapat pohon kelapa, kangkung laut, kenikir dan pohon mangrove dibagian ujung utara pantai dan selatan. Dengan keragaman flora yang sangat baik sepanjang pantai Pas Ipa juga dihiasi dengan pasir putih. Apalagi jika pasang surut tiba maka luas pasir putih semakin besar, bisa sampai 50 meter dari tepi pantai. Batas pasang surut yang begitu luas tentu kedalaman air laut juga sangat rendah. Hal ini juga yang ada pada Pantai Pas Ipa, jika pasang naik tingkat 
Hernita Pasongli, Ramdani Salam, Wahyudi Tempola, 2021, Kesesuaian Objek Wisata Pantai Pas Ipa Kecamatan Mongoli Barat Kabupaten Kepulauan Sula

kedalaman tidak sampai 2 meter khususnya di area pasir putih. Bahkan pada bulan-bulan tertentu air laut tidak mencapai 2 meter sehingga sangat baik bagi wisatawan untuk mandi di area pantai Pas Ipa.

Salah satu pengamatan fisik dari obyek wisata pantai adalah kemiringan lereng. Pada pantai Pas Ipa sangat datar, sehingga sangat baik kesesuaian lahan pada parameter kemiringan lereng. Meski sangat data pada pantai Pas Ipa untuk akses dari ibu kabupaten hanya bisa dijangkau dengan transportasi laut (Kapal Laut, Speed boat, long boat) hal ini karena letak pantai Pas Ipa yang berada di kecamatan mangoli barat. selain itu parameter lain yang dilakukan pengamatan pada Pantai Pas Ipa adalah mengenai kecerahan air laut, pada pantai Pas Ipa kecerahan sangat baik. Kemudian lebar pantai Pas Ipa juga sangat sesuai untuk dijadikan lahan obyek wisata.

Dari segi parameter fisik pantai Pas Ipa sangat sesuai untuk dijadikan obyek wisata pantai meski demikian fasilitas sarana dan prasarana meski ditingkatkan. Hal ini berdasarkan pengamatan bahwa sarana dan prasarana masih sangat kurang. Untuk pemerintah desa harus lebih proaktif komunikasi dengan dinas terkait pada pemerintah kabupaten kepulauan sula untuk meningkatkan sarana dan prasarana pada pantai pas ipa.

\section{PETA KESESUAIAN LAHAN OBYEK WISATA PANTAI PAS IPA}

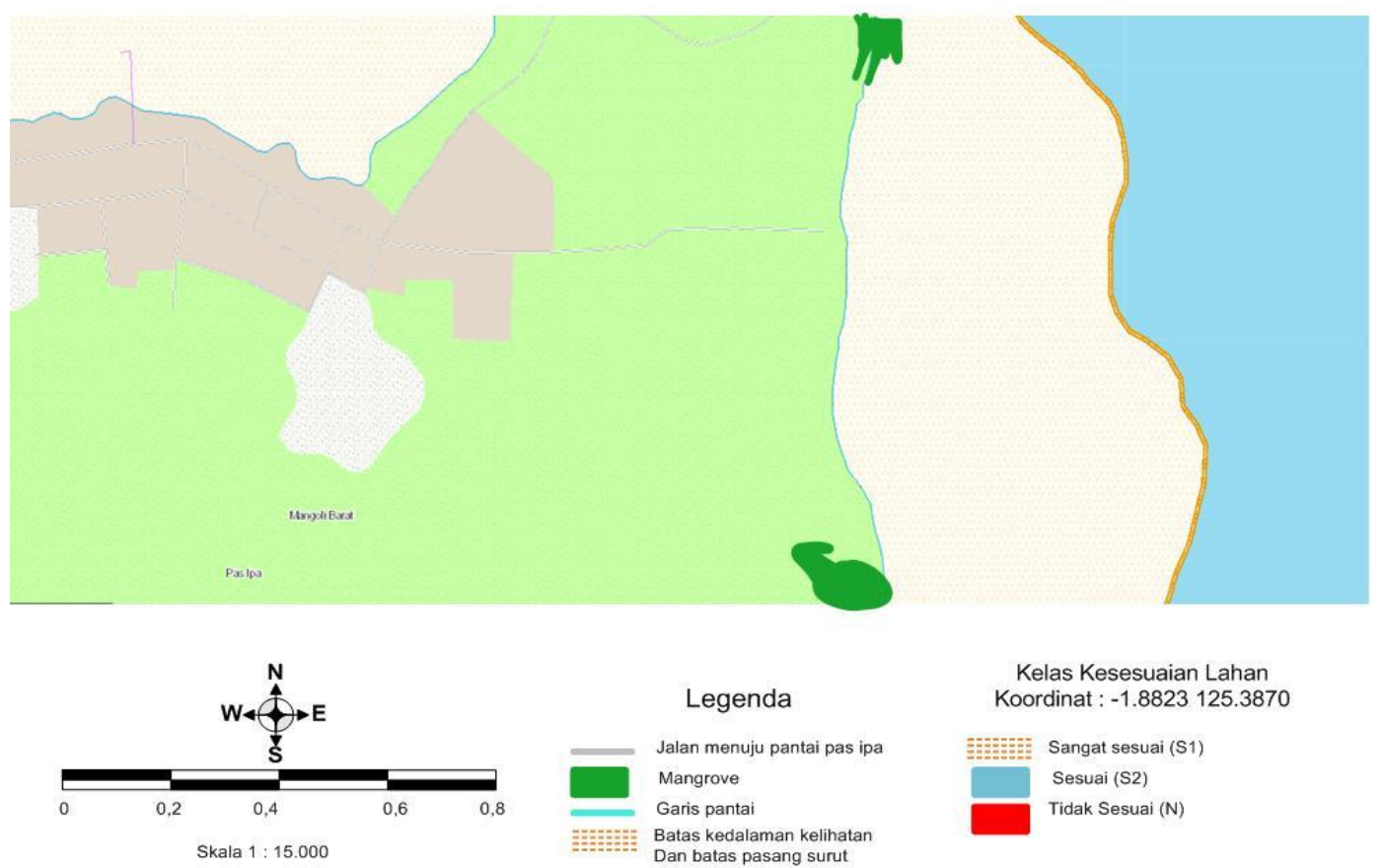

Gambar 3. Peta Kesesuaian Lahan Pariwisata Pantai Pas Ipa

Namun dari segi faslitas pantai Pas Ipa masih perlu mendapat perhatian lebih untuk meningkatkan fasilitas berupa sarana dan prasarana di pantai Pas Ipa. Salah satu indikator kepuasan wisatawan di suatu objek wisata yaitu dengan menyediakan aksebilitas menuju lokasi 
destinasi, sarana dan prasarana yang menunjang di lokasi tersebut serta fasilitas-fasilitas yang mendukung di obyek wisata tersebut (Istiana et al., 2021). Hal serupa juga diungkapkan oleh (Pratiwi et al., 2021) bahwa sektor pariwisata yang dikelola dengan baik juga akan menambah pemasukan. Menurut (Makkasau et al., 2021) bahwa dengan adanya pariwisata menyebabkan meningkatnya pendapatan bagi daerah maupun bagi masyarakat setempat. selain itu faktor objek Geografi memiliki peran dalam kemajuan objek wisata (Jasman \& Ridwan, 2020). Adapun peta kesesuaian lahan ditunjukkan pada Gambar 3.

\section{SIMPULAN DAN SARAN}

\section{Simpulan}

Berdasarkan hasil penelitian kesesuaian lahan wisata Pantai di Desa Pas Ipa, Kecamatan Mangoli Barat, Kabupaten Kepulauan Sula dapat disimpulkan bahwa tingkat Kesesuaian Wisata Pantai Pas Ipa berdasarkan hasil perhitungan indeks kesesuaian wisata (IKW), pada dengan titik koordinat (-1.8823 125.3870 ), diperoleh nilai $90 \%$, kategori S1 (sangat sesuai). Fasilitas sarana dan prasarana yang tersedia di pantai Pas Ipa masih sangat kurang. Seperti tempat makan, pelayanan wisata dan tempat parkir. Sehingga berdasarkan hasil tersebut maka, tingkat Kesesuaian Lahan Wisata Pantai Pas Ipa, sangat layak dijadikan sebagai lokasi pariwisata Kabupaten Kepulauan Sula, dengan spesifikasi pada sektor wisata pantai.

\section{Saran}

Pemerintah dan masyarakat harus bekerja sama untuk meningkatkan kualitas pariwisata Kabupaten Kepulauan Sula, dalam hal mengembangkan lebih baik lagi wisata pantai, di Desa Pas Ipa, Kecamatan Mangoli Barat, Kabupaten Kepulauan Sula. Sarana prasarana harus lebih diperhatikan serta membuka ruang komunikasi dengan instansi setempat terutama dinas pariwisata agar mempromosi obyek wisata pantai Pas Ipa.

\section{DAFTAR RUJUKAN}

Arikunto, S. (2019). Prosedur penelitian.

Badan Pusat Statistik Kabupaten Kepulauan Sula. (n.d.). Retrieved October 17, 2021, from https://kepsulkab.bps.go.id/publication/2020/04/27/0f337da83572810184c8c3f7/kabupate n-kepulauan-sula-dalam-angka-2020.html

Banowati, E. (2014). Geografi Indonesia. Ombak Yogyakarta.

Erwin, E., \& Zhiddiq, S. (2020). PENGEMBANGAN HUTAN WISATA EKO PENELITIAN DAN WISATA KAYU BESI (METROSIDEROS) DI DESA TEMBOE KECAMATAN LAROMPONG SELATAN KABUPATEN LUWU. Jurnal Environmental Science, 3(1). https://ojs.unm.ac.id/JES/article/view/15361

Hutabarat, A. A. F., Yulianda, A., Fahrudin, S., \& Harteti, K. (2009). Pengelolaan pesisir dan laut secara terpadu. Pusdiklat Kehutanan Departemen Kehutanan RI. SECEM-Korea International Coorporation Agency. Bogor. 
Istiana, A. N., Maru, R., \& Abbas, I. (2021). The Attraction and Satisfaction of Tourists Apparalang Attractions Bulukumba Regency. UNM Geographic Journal, 4(1), 1-12. https://ojs.unm.ac.id/UGJ/article/view/22825

Jasman, J., \& Ridwan, M. (2020). Strategi Pengembangan Kawasan Wisata Gunung Nona Kecamatan Anggeraja Kabupaten Enrekang, Indonesia. LaGeografia, 18(2), 187-190.

Makkasau, N., Maru, R., \& Nyompa, S. (2021). Peran Pemerintah dalam Pengembangan Objek Wisata Pulau Camba-cambang Kabupaten Pangkep. UNM Geographic Journal, 3(2), 167174. https://ojs.unm.ac.id/UGJ/article/view/22852

Mustafa, P. R. D., Syarif, E., \& Badwi, N. (2020). Kontribusi Kawasan Wisata Budaya Dayak Terhadap Tingkat Pendapatan Masyarakat Suku Dayak Kenyah. LaGeografia, 18(2), 117128.

Noor, Y. R., Khazali, M., \& Suryadiputra, I. N. N. (2006). Panduan pengenalan mangrove di Indonesia. Ditjen PHKA.

Pasongli, H., Aryuni, V. T., \& Sirajudin, N. (2020). Mangrove Suitability for Ecotourism Location in Tuada Village, Jailolo, West Halmahera.

Pasongli, H., \& Dirawan, G. D. (2016). Zonasi Kesesuaian Tambak Untuk Pengembangan Budidaya Udang Vaname (Penaeus Vannamei) Pada Aspek Kualitas Air Di Desa Todowongi Kecamatan Jailolo Kabupaten Halmahera Barat. BIOEDUKASI, 3(2).

Pratiwi, D., Yusuf, M., \& Maddatuang, M. (2021). Development of Blue Lake Tourism Objects Using SWOT Analysis in Walasiho Village, Wawo District, North Kolaka Regency. UNM Geographic Journal, 4(1), 47-56. https://ojs.unm.ac.id/UGJ/article/view/22864

Rahmawati, A. (2009). Studi Pengelolaan Kawasan Pesisir untuk Kegiatan Wisata Pantai (Kasus Pantai Teleng Ria Kabupaten Pacitan, Jawa Timur).

Rinaldi, A., Citra, I. P. A., \& Christiawan, P. I. (2020). Strategi Pengembangan Wilayah Pesisir di Kecamatan Seririt Kabupaten Buleleng. LaGeografia, 19(1), 71-87.

Rudiastuti, R. (2011). Evaluasi Kesesuain Lahan dan Pengembangan Sistem Informasi Budaya Tambak Udang PT. Indonesia Yudha Perwita. Institut Pertanian Bogor (ITB).

Saputro, A., Nyompa, S., \& Arfan, A. (2019). Analisis Pemanfaatan Hutan Mangrove dan Kontribusinya Terhadap Pendapatan Rumah Tangga Masyarakat di Pulau Tanakeke Kabupaten Takalar. LaGeografia, 18(1), 70-81.

Sugiyono, P. (2019). Metode Penelitian Pendidikan (Kuantitatif, Kualitatif, Kombinasi, R\&D dan Penelitian Pendidikan) (A. Nuryanto (Ed.); Ke-3). Alfabeta.

Suharsimi, A. (2006). Prosedur penelitian suatu pendekatan praktik. Jakarta: Rineka Cipta.

Sukmadinata Nana, S. (2010). Metode Penelitian Pendidikan. Bandung: Remaja Rosdakarya.

Zulharman, Z., Junaidin, J., Khaldun, I., \& Santoso, H. (2017). KEARIFAN LOKAL MASYARAKAT DESA SAMBORI DALAM PENGELOLAAN SUMBERDAYA ALAM DAN POTENSI EKOWISATA. Jurnal Ilmiah Mandala Education, 3(2), 189198. http://ejournal.mandalanursa.org/index.php/JIME/article/view/201 